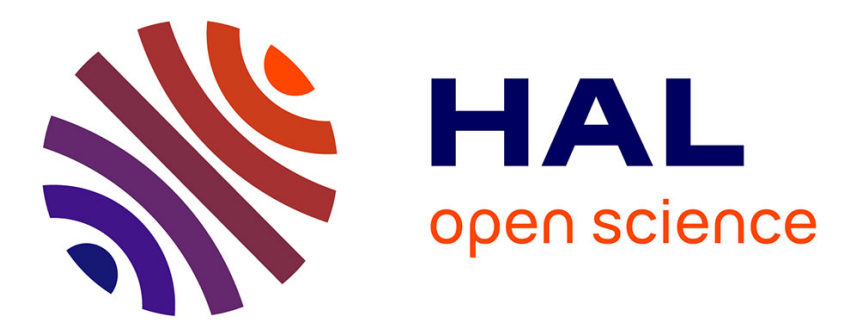

\title{
The prescriptive power of the television host. A transposition of Milgram's obedience paradigm to the context of TV game show
}

Jean-Léon Beauvois, Didier Courbet, Dominique Oberlé

\section{- To cite this version:}

Jean-Léon Beauvois, Didier Courbet, Dominique Oberlé. The prescriptive power of the television host. A transposition of Milgram's obedience paradigm to the context of TV game show. European Review of Applied Psychology / Revue Européenne de Psychologie Appliquée, 2012, 62 (3), pp.111119. sic_00765320

\section{HAL Id: sic 00765320 \\ https://archivesic.ccsd.cnrs.fr/sic_00765320}

Submitted on 14 Dec 2012

HAL is a multi-disciplinary open access archive for the deposit and dissemination of scientific research documents, whether they are published or not. The documents may come from teaching and research institutions in France or abroad, or from public or private research centers.
L'archive ouverte pluridisciplinaire HAL, est destinée au dépôt et à la diffusion de documents scientifiques de niveau recherche, publiés ou non, émanant des établissements d'enseignement et de recherche français ou étrangers, des laboratoires publics ou privés. 
Provided for non-commercial research and education use. Not for reproduction, distribution or commercial use.

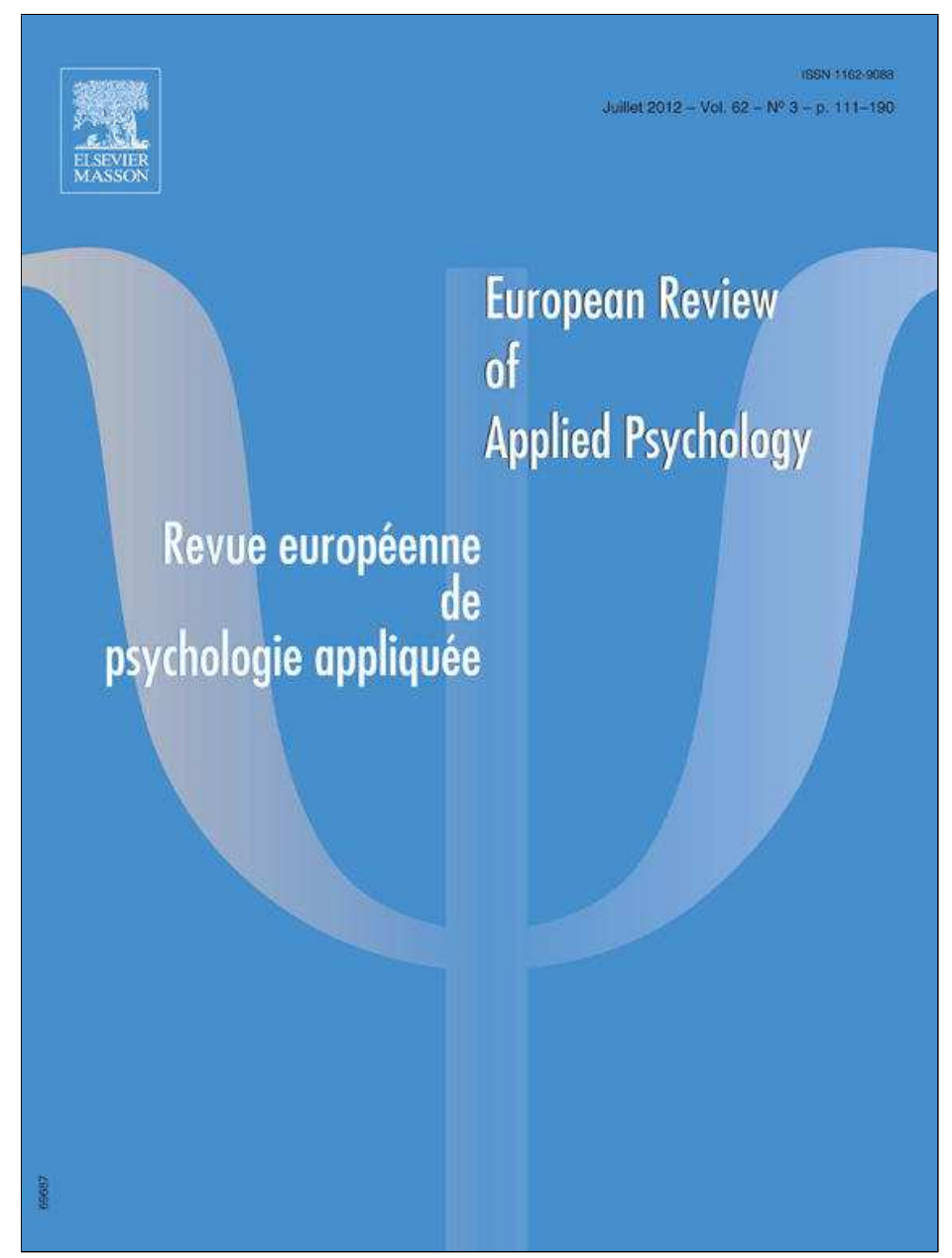

This article appeared in a journal published by Elsevier. The attached copy is furnished to the author for internal non-commercial research and education use, including for instruction at the authors institution and sharing with colleagues.

Other uses, including reproduction and distribution, or selling or licensing copies, or posting to personal, institutional or third party websites are prohibited.

In most cases authors are permitted to post their version of the article (e.g. in Word or Tex form) to their personal website or institutional repository. Authors requiring further information regarding Elsevier's archiving and manuscript policies are encouraged to visit:

http://www.elsevier.com/copyright 


\title{
The prescriptive power of the television host. A transposition of Milgram's obedience paradigm to the context of TV game show
}

\section{Le pouvoir prescriptif de l'animateur de télévision. Une transposition du paradigme de l'obéissance de Milgram dans le contexte d'un jeu télévisé}

\author{
J.-L. Beauvois ${ }^{\mathrm{a}, *}$, D. Courbet $^{\mathrm{b}}$, D. Oberléc $^{\mathrm{c}}$ \\ a 223, route de Marseille, 83670 Barjols, France \\ b IRSIC, IUT d'Aix-en-Provence, Aix-Marseille University, 413, avenue Gaston-Berger, 13625 Aix-en-Provence, France \\ ${ }^{c}$ University of Paris-Ouest Nanterre La Defense, Department of Psychology, 200, avenue de la République, 92700 Nanterre, France
}

\section{A R T I C L E I N F O}

\section{Article history:}

Received 24 January 2011

Received in revised form 3 February 2012

Accepted 7 February 2012

\section{Keywords:}

Television violence

Reality television

Authority

Milgram

Obedience

\begin{abstract}
A B S T R A C T
Introduction. - Today's fascination with television makes us wonder whether it might not represent an authority capable of leading people in a television studio to inflict cruel acts on others, even though they condemn those acts.

Objective. - The experiment reported here allows us to answer this question in the affirmative. Therefore, we transposed Milgram's famous experimental obedience paradigm to the context of a "real" TV game show, in the studio of a large television production company, with a live audience and no prizes.

Method. - We set up several experimental conditions designed to tell us if, in such contexts, obedience was the dominant response, as it is in the often-replicated classic situation. We also wished to know if the introduction of variations would reduce obedience.

Results. - The results show that obedience to the host is the dominant response, as it is in Milgram's classic situation. However, variations that are assumed to reduce this obedience do not in fact demonstrate the expected effects. An additional experimental condition appears to demonstrate that a determining factor of obedience is the physical proximity of the host incarnating the televisual power. Conclusion. - We offer a conclusion addressing the societal aspects of obedience.
\end{abstract}

(c) 2012 Published by Elsevier Masson SAS.

\section{R É S U M É}

Introduction. - Vu la fascination qu'exerce aujourd'hui la télévision, on se demande si elle ne représente pas une autorité susceptible de conduire les gens à commettre, sur un plateau de télévision, des actes cruels à l'égard d'autrui, actes que pourtant ils réprouvent.

Objectifs. - La présente expérience nous permet de répondre affirmativement à cette question. Pour le démontrer, nous avons transposé le célèbre paradigme d'obéissance de Milgram dans le contexte d'un jeu télévisé, filmé dans le studio d'une entreprise de production d'émissions télévisées, impliquant un public mais pas de gains.

Méthode. - Nous avons réalisé plusieurs conditions expérimentales destinées à faire apparaître si, dans un tel contexte, l'obéissance restait, comme dans la situation classique souvent reproduite, la réponse dominante. Nous souhaitions aussi savoir si l'introduction de variantes permettrait d'obtenir, une réduction de l'obéissance.

Résultats. - Les résultats montrent que l'obéissance à l'animatrice est, comme dans la situation standard de Milgram, la réponse dominante et que des variantes supposées a priori réduire cette obéissance ne la réduisent pas. Une condition expérimentale additionnelle semble indiquer qu'un facteur déterminant de l'obéissance est la proximité physique de l'animatrice représentant le pouvoir télévisuel. Conclusion. - On conclut en évoquant les aspects sociétaux de l'obéissance.

(ㄷ) 2012 Publié par Elsevier Masson SAS.

\footnotetext{
is We would like to thank Olivier Codou, Julien Intartaglia, Amandine Tonelli and David Vaidis for their participation in the experiment's execution and particularly for creating the debriefings. We'd like to thank France Télévision, Christophe Nick and the Yami 2 team for allowing us to perform this experiment.

* Corresponding author.

E-mail addresses: jlbeauvois@wanadoo.fr (J.-L. Beauvois), didier.courbet@univ-amu.fr (D. Courbet), oberle.dominique@wanadoo.fr (D. Oberlé).
} 
Though the effects of television on viewers are complex and sometimes difficult to demonstrate experimentally (McGuire, 1986), there is a large body of research indicating the significant impact of television on people's behavior (Berkowitz, 1986; Bryant and Oliver, 2009). Nevertheless, to our knowledge, there are few studies which demonstrate the authority or prescriptive power held by the television world and its representatives. Yet, is not televisual authority at work and particularly striking in game shows during which, based on a single order given by the game host, contestants perform violent acts against others or against themselves? We wanted to find out whether, at the present time, television is able to endow certain agents - such as TV show hosts - with a degree of authority that gives them the power to make game-show contestants commit dangerous acts or acts they condemn. To demonstrate this, we transposed Milgram's obedience-to-authority paradigm (Milgram, 1963, 1974) to a TV game show setting where a female host (an accomplice of the experimenters) asked people to deliver (fake) electric shocks to other persons ${ }^{1}$. Our study, then, is not just another replication of Milgram's laboratory experiments to be added to the list, the difference being that in the Milgram replications, it was the status of scientific researcher that granted legitimacy to the agent of authority (Blass, 2009). In the transposed version reported here, although we stayed as close as possible to Milgram's obedience paradigm and electric-shock procedure, our experiment takes place in a totally different social context, one where the authority derives its legitimacy from another entity, the television show. From the subjects' standpoint, the experiment was not a scientific study but a game show taking place in front of a live audience. Our goal was to see whether and when people would comply with, or resist, the televisual authority incarnated by the host of the game.

\section{Theoretical background}

In 1963 -in one of the most famous studies in psychology - Stanley Milgram (1963) showed that ordinary Americans participating in an experiment on how punishment affects memory agreed to satisfy the request of a researcher - an agent of authority who urged them to continue with the experiment - by acting as a "professor" and delivering dangerous electric shocks (that were in fact fictitious) to a "student". Nearly 50 years later, this research continues to generate new analyses, commentaries and reinterpretations (De Vos, 2010; Reicher and Haslam, 2011; Russell, 2011). Although certain situations did indeed produce disobedience (in particular, the absence of the researcher), the most striking thing for everyone - especially Milgram - was the obedience rate obtained, already in 1963. In that study, $62.5 \%$ of the "professors" went all the way up to 450 volts. Given the spectacular nature of both the situation and the findings, Milgram's experiment was reproduced on more than 3000 persons, recruited from 12 different countries, and every time, the same results were obtained (Blass, 1999). Meanwhile, many objections were raised condemning the experiment (see Miller, 1986). This is why Burger (2009) recently suggested that during replications of Milgram's experiment, subjects should not be asked to send shocks above 150 volts. Indeed, as Packer (2008) points out, this voltage represents a critical juncture in the course of the experiment. In addition, the rate of disobedience cannot be explained by the student's growing cries and supposed suffering, which follow the voltage increase.

1 This research was approved by the French Society of Information Science and Communication Science (SFSIC). It was considered that the research met the ethical standards of research on humans, including informed consent. For more information on developments concerning the ethical aspects of this experiment, see Oberlé et al. (2011).
The various reproductions always took place in the same context (the one designed by Milgram): a scientific study conducted in a laboratory, with the agent of authority drawing his legitimacy from his status as a research scientist. There is one exception, however. In their fascinating study, Meeus and Raaijmakers $(1986,1987)$ transposed the Milgram paradigm to an organizational setting in which the suffering inflicted by the experimental subjects was not physical but psychological. Subjects had to obey an alleged head of personnel's order to disturb an applicant during a job interview. The obedience rate in this organizational setting almost hit the $100 \%$ mark. However, although their reproduction retained Milgram's basic framework, it did not re-use the electric-shock procedure. In the transposition we present here, we stayed as close as possible to Milgram's obedience paradigm and electric-shock procedure, but we inserted it in television show setting, similar to the way Haslam and Reicher (2006) transposed Zimbardo's Stanford prison experiment to the BBC. To do so, and contrary to Burger's (2009) suggestion, we performed an identical replication of the complete electric shock procedure (up to 460 volts). Burger's main reason for limiting the voltage strength is an ethical one: surpassing 150 volts imposes too much suffering and thus too much guilt on obedient subjects. We believe that this ethical standard is more comfortable than rigorous. It is the very willingness to harm a fellow human being which is immoral, regardless of the degree of suffering being inflicted. Moreover, for credibility reasons, transposing the experiment into a televised game setting requires the use of violence equivalent to that frequently implemented in some of these games.

We thus wondered what would happen if the agent of authority drew her legitimacy solely from her association with the world of television. Given the importance of television in our society, it seems both legitimate and necessary to raise this question.

Our assumption is that the authority is incarnated by the game host. While the persuasive influence of hosts is now widely recognized (Nabi and Hendriks, 2003), it is the host's prescriptive power which we would like to make apparent and whose potential limits we would like to test. This power is related to the statutory position occupied in an organizational structure and results from a delegation of power (Coenen-Huther, 2005). It thus does not depend on the delegated person's level of prestige. In fact, the prestige of the hosts, which depends on their relative popularity, primarily relates to their leadership capacities. Moreover, in Milgram's case, when the notion of prestige is mentioned, it relates to science as a whole, and not to the scientist giving orders. Similarly, we can consider the host to be the recipient of a power delegation from the televisual authority.

Thus, based on our assumption that authority is incarnated by the game host, we set up three experimental conditions designed to tell us when people would obey the televisual authority and when they would resist it. We wanted to know whether, in this context, obedience would remain the dominant response, as in the classic situation; and whether introducing a variation which reduces obedience in the classic situation (social support for disobedience) would have the same effect in a televisual context. Finally, a specific condition was introduced for the televisual context (see section 2.3 [Experimental subjects and experimental conditions]).

\section{Method}

\subsection{Experimental setting}

The experiment took place in a television studio. An original game show was set up on stage with the help of technical devices (cameras, lighting, giant screen, control room, etc.) and human resources (81 persons) from several companies specializing in the production of game shows on French TV. As such shows, there was 
a live audience in the seating areas around the stage. The audience consisted of about 100 persons of all ages who had answered a short ad on the Internet posted by a company specializing in the recruitment of game-show audiences. In order to account for any obedience observed, we had to eliminate all causes other than pure obedience to authority, such as the desire to win money. So that no rewards would be at stake, we set up a pilot show in which the participants were filmed in "real conditions" but told that the purpose was to test the game and improve it if necessary.

\subsection{Experimental requirements}

Our transposition to the television setting had to satisfy two requirements. The first consisted of staying as close as possible to Milgram's experimental situation while putting the subjects in a credible televisual context. Following a discussion with television producers and filmmakers, we decided that a game show reproducing Milgram's situation (a naive questioner is asked by a TV show host to deliver electric shocks) would meet these requirements if we could eliminate the motivation to participate in order to win money. Our next step was to test the credibility of the game show on the producers and TV channel (France 2) that had agreed to fund the experiment and incorporate it into a documentary on the risks of certain reality TV games. To be credible, the experiment had to be conducted in a real television studio, and real television staff had to be trained to work in their usual way, while nevertheless meeting the rigorous requirements of a scientific experiment. This meant not changing the scenario once it was adopted, replying to questions using the exact material found in the scenario, and so on. The scenario was pre-tested on a few technicians from the filming staff and then on the first questioner in each experimental condition. It worked perfectly.

The second requirement was to make sure that the rapport between the agent of authority and the agent subjected to that authority was very close to the one created by Milgram. To verify this, we established a list of 15 criteria for analyzing situations of power involving an asymmetrical relationship between two persons, one who makes behavioral prescriptions and the other who is supposed to obey (Table 1). The two situations (our game show and Milgram's scientific laboratory) turned out to be very close for all 15 criteria $^{2}$.

These precautions allowed us to conclude that the televisual framing of Milgram's paradigm in no way modified the basics, the type of relationship between the person giving the instructions and the person receiving them, and thus that in power-based and situation-based terms, the host-questioner rapport in the present study was very close to the researcher-professor situation in Milgram's study.

\subsection{Experimental subjects and experimental conditions}

Seventy-six ordinary people were selected from a consumer database by an independent company that conducts opinion polls and market studies. They each received 40 euros. Subjects who had already participated in a game show were not eligible,

\footnotetext{
2 The great similarity between the two situations (15 of 15 common traits) is not a triviality due to an eventual bias driven by our analysis grid (e.g. lack of sensitivity). To demonstrate this, we mentioned two other power relationships in Table 1: the Foreman/Worker relationship and the Social Worker/Socially Disadvantaged Person relationship. It appears that the researcher/teacher relationship and the host/questioner relationship share only six traits (out of 15) with the Foreman/Worker relationship and seven traits (out of 15) with the Social Worker/Socially Disadvantaged Person relationship. It is indeed because they are very similar in the area of possible power relationships that the relationships implemented in Milgram's and our experiments share the same traits.
}

nor were persons who had health problems or were taking any kind of medication. The experimental population was from the Parisian area. The characteristics of the sample are given in Tables 2 and 3. The televisual context of the experiment (renting a studio, hiring technicians, the host's schedule, etc.) restricted us to a predetermined number of days for the experiment, and thus a predetermined number of subjects were asked to participate (80). Four subjects had to be eliminated because they were already familiar with Milgram's research.

The experimental subjects were assigned to one of the following conditions ${ }^{3}$.

\subsubsection{Standard condition $(n=32)$}

This condition was similar to Milgram's "voice-feedback" condition (Milgram, 1974, Experiment 2). A "questioner" (the experimental subject) asked 27 questions to a "contestant" (an accomplice of the experimenter) who could be heard but not seen. Every time the contestant gave an incorrect answer (according to a predetermined schedule of 24 incorrect answers out of 27), the questioner was to penalize him by delivering an (alleged) electric shock. The shocks ranged between 20 and 460 volts, and were to be increased by 20 volts with each new mistake. The game host had five prods at her disposal for encouraging reluctant subjects to continue: four were similar to the ones used by Milgram, and the fifth was specific to the TV-show setting (asking the audience to intervene).

\subsubsection{Social-support condition $(n=19)$}

This condition was the same as the standard condition, except that when the voltage reached 120 , the production assistant (an accomplice) rushed out on stage and asked that the game be stopped because it was too immoral. The assistant was brushed aside by the host, who went on with the game.

\subsection{3. $T V$-broadcast condition $(n=18)$}

This condition was the same as the standard condition, except that upon arrival, the questioner and alleged contestant were told that the TV station would broadcast the pilot show. The players would be on TV but would still not win any money.

Immediate observation of the set, even before statistical data analysis, showed that the social support condition, which was supposed to produce disobedience, was not producing the expected effect. This observation led us to introduce a new condition, not included in the original design, which we tested on the remaining subjects.

\subsubsection{Host-withdrawal condition $(n=7)$}

This condition was similar to Milgram's condition in which the researcher leaves the experiment ("experimenter absence", Milgram, 1974, Experiment 7). Upon reaching 80 volts, the host explained that from now on, the players would continue on their own. Then the host went off stage and did not come back until the game was over.

All four conditions will be taken into account in the discussions which follow, though the small number of subjects in the fourth condition warrants some caution.

\subsection{Procedure}

An alleged producer received each participant along with another person who was in fact a male accomplice of the experimenter. The producer told them that they would be filmed

\footnotetext{
${ }^{3}$ Informed consent was obtained from the subjects after they were told that the game involved delivering electric shocks.
} 
Table 1

Comparison of the power structure in Milgram's experiment and in the TV game show, according to the 15 criteria for analyzing situations of power. Comparaison de la structure du pouvoir dans l'expérience de Milgram et dans le jeu TV, selon 15 critères d'analyse des situations de pouvoir.

\begin{tabular}{|c|c|c|c|c|c|}
\hline Criterion for analyzing situations of power & $\begin{array}{l}\text { Milgram's } \\
\text { experiment }\end{array}$ & TV game show & $\begin{array}{l}\text { Conclusion of } \\
\text { two-situation } \\
\text { comparison }\end{array}$ & Foreman/worker & $\begin{array}{l}\text { Social } \\
\text { worker/socially } \\
\text { disadvantaged } \\
\text { person }\end{array}$ \\
\hline $\begin{array}{l}\text { 1. Insertion in a dependence structure: there } \\
\text { exists a formal structure where A and B } \\
\text { occupy asymmetrical positions }\end{array}$ & No & No & Same situation & Yes & Yes \\
\hline $\begin{array}{l}\text { 2. Prescription of obligations (“Do!"): A is } \\
\text { authorized to make B do something that B } \\
\text { would not willingly do otherwise }\end{array}$ & Yes & Yes & Same situation & Yes & Yes \\
\hline $\begin{array}{l}\text { 3. Prescription of prohibitions (“Do not!”): A is } \\
\text { authorized to prevent B from doing } \\
\text { something that B would like to do }\end{array}$ & No & No & Same situation & Yes & Yes \\
\hline $\begin{array}{l}\text { 4. Formal evaluation of B by A: the evaluation } \\
\text { must have other consequences on the } \\
\text { evaluated person than interpersonal ones } \\
\text { (e.g. some other person who will be } \\
\text { informed of the evaluation will "have the } \\
\text { right" to make decisions about B) }\end{array}$ & No & No & Same situation & Yes & Yes \\
\hline $\begin{array}{l}\text { 5. There exist possibilities for positive } \\
\text { reinforcement that A can use to B's benefit }\end{array}$ & No & No & Same situation & Yes & Yes \\
\hline $\begin{array}{l}\text { 6. There exist possibilities for negative } \\
\text { reinforcement that A can use to B's detriment }\end{array}$ & No & No & Same situation & Yes & Yes \\
\hline $\begin{array}{l}\text { 7. Operatory interdependence: what B does } \\
\text { depends on what A does, but also, what A } \\
\text { does depends on what B does }\end{array}$ & Yes & Yes & Same situation & Yes & Yes \\
\hline $\begin{array}{l}\text { 8. Existence of relatively well-acknowledged } \\
\text { values assumed to justify the situation of } \\
\text { dependence: these values must be general } \\
\text { enough to be transitive with respect some } \\
\text { other, even-more-general value }\end{array}$ & Yes, science & Yes, the game show & Same situation & Yes & Yes \\
\hline $\begin{array}{l}\text { 9. Extent of dependence: A's authority can be } \\
\text { brought to bear to affect B's behaviors or } \\
\text { thoughts elsewhere than in the } \\
\text { interdependence situation defined for the } \\
\text { B-on-A dependence situation (e.g. for } \\
\text { controlling B's private life, dress habits, } \\
\text { language) }\end{array}$ & No & No & Same situation & No & Yes \\
\hline $\begin{array}{l}\text { 10. Specific material or psychological benefits } \\
\text { of the interaction situation common to both } \\
\text { persons: these benefits must be shared, } \\
\text { known, and nameable (more than the mere } \\
\text { interest or desire to participate) }\end{array}$ & No & No & Same situation & Yes & No \\
\hline $\begin{array}{l}\text { 11. Specific material or psychological costs of } \\
\text { the interaction situation common to both } \\
\text { persons }\end{array}$ & No & No & Same situation & Yes & No \\
\hline $\begin{array}{l}\text { 12. B can make a formal appeal (on his/her } \\
\text { own, or by appealing to the opposition) in } \\
\text { case of misuse of power }\end{array}$ & Yes, legal recourse & Yes, legal recourse & Same situation & Yes & Yes \\
\hline $\begin{array}{l}\text { 13. Social backing: behind the delegation of } \\
\text { power to A, there is social backing (religious, } \\
\text { political, economic, etc.) accepted by B and } \\
\text { by a large part of the population; A's power } \\
\text { is not obtained via usurpation }\end{array}$ & $\begin{array}{l}\text { Yes, } \\
\text { science-related }\end{array}$ & $\begin{array}{l}\text { Yes, } \\
\text { television-related }\end{array}$ & Same situation & Yes & Yes \\
\hline $\begin{array}{l}\text { 14. } \mathrm{A} \text { is responsible in front of a third party } \\
\text { licensed to make judgments about what } \\
\text { happens between B and him/herself }\end{array}$ & Yes & Yes & Same situation & Yes & Yes \\
\hline $\begin{array}{l}\text { 15. A absolutely must have ongoing } \\
\text { surveillance (in real time) over B; without } \\
\text { this surveillance, the probability that B will } \\
\text { disobey is great }\end{array}$ & Yes & Yes & Same situation & No & No \\
\hline
\end{tabular}

$\mathrm{A}$ is the person who has the power. B is the dependent person subjected to that power. For comparison, analysis of the foreman/worker relation: seven shares traits. For comparison, analysis of the social worker/socially disadvantaged person relation: eight shares traits.

as they participated together as players in a TV game show. Because the filming was said to be for a pilot show aimed at testing the game "under real conditions" and improving it if need be, they were informed that they would not win any money, unlike the future game contestants who would try together to win a million euros. In three conditions out of four, the players were also told that the film would not be broadcasted on TV. For one of the players ("the questioner"), the task consisted of asking questions; for the other ("the contestant"), the task was to answer correctly. They were told that the penalty for each incorrect answer would be an electric shock delivered by the "questioner" to the "contestant". The alleged producer then had the subjects draw straws to determine which person would play which role. The drawing was rigged so that the experimental subject was always the questioner and the 
Table 2

Characteristics of the sample: gender, age, and reality-TV watching.

Caractéristiques de l'échantillon: sexe, âge et consommation de télé-réalité.

\begin{tabular}{|c|c|c|c|}
\hline & \multicolumn{2}{|l|}{ Gender } & \multirow[t]{2}{*}{ Total $(n)$} \\
\hline & Male $(n)$ & Female $(n)$ & \\
\hline Experimental population & 40 & 36 & $\begin{array}{l}76 \\
18 \text { of whom }(23.7 \%) \\
\text { were avid watchers of } \\
\text { reality TV }\end{array}$ \\
\hline \multicolumn{4}{|l|}{ Age group } \\
\hline $25-29$ & 8 & 6 & $\begin{array}{l}14 \\
3 \text { of whom }(21.4 \%) \\
\text { were avid watchers of } \\
\text { reality TV }\end{array}$ \\
\hline $30-34$ & 7 & 5 & $\begin{array}{l}12 \\
3 \text { of whom (25\%) were } \\
\text { avid watchers of reality } \\
\text { TV }^{\mathrm{a}}\end{array}$ \\
\hline $35-39$ & 7 & 7 & $\begin{array}{l}14 \\
3 \text { of whom }(21.4 \%) \\
\text { were avid watchers of } \\
\text { reality TV }\end{array}$ \\
\hline $40-44$ & 6 & 7 & $\begin{array}{l}13 \\
3 \text { of whom (23\%) were } \\
\text { avid watchers of reality } \\
\text { TV }^{\mathrm{a}}\end{array}$ \\
\hline $45-49$ & 6 & 6 & $\begin{array}{l}12 \\
3 \text { of whom (25\%) were } \\
\text { avid watchers of reality } \\
\text { TV }^{\mathrm{a}}\end{array}$ \\
\hline $50-55$ & 6 & 5 & $\begin{array}{l}11 \\
3 \text { of whom (27\%) were } \\
\text { avid watchers of reality } \\
\text { TV }^{\mathrm{a}}\end{array}$ \\
\hline Mean age (in years) & 39.6 & 39.8 & 39.7 \\
\hline
\end{tabular}

\footnotetext{
a At least four French reality-TV shows watched on a regular basis.
}

accomplice was always the contestant. Once this information was given, the producer asked the players if they still wanted to participate in the pilot. No one refused.

After a make-up session, the two players were led on stage where they were awaited by the game host (a female weather forecaster for a French national TV station), the audience, and a warm-up comedian whose job was to organize the applause and encouragements to continue the game. Then, in front of the camera, the host explained the game as follows. The contestant would be given a limited amount of time to learn a list of 27 pairs of related words (e.g., cloudy-sky, tame-animal, etc.). Then the questioner would say the first word in each pair and the contestant would have to find the related word among the four words proposed. If the contestant made a mistake, the questioner was to deliver an electric shock, increasing the shock's intensity each time. The team of players would win if they were able get through all 27 questions (whether or not the answers were correct or incorrect and penalized by an electric shock). Once these rules were stated, the contestant was taken into a chamber where he would not be seen by the questioner or the audience. In front of everyone, before the door of the chamber was closed, the contestant was strapped to the chair in which he would receive the shocks, and shown the buttons to press to choose the right answer. The questioner was seated at a desk in the center of the stage, under the projectors and cameras, with his/her back to the audience and facing a giant screen where the questions would be displayed in succession. The questioner was shown the handles to be used to deliver the (fake) electric shocks to the contestant, with an increase of 20 volts for each new wrong answer. The shocks ranged from 20 volts to 460 volts and were grouped together in sets labeled:

- Slight Shocks (20, 40, 60 volts);

Table 3

Socio-occupational characteristics of sample.

Catégories socioprofessionnelles de l'échantillon.

\begin{tabular}{|c|c|}
\hline Social category: social class (occupation) & $n(\%)$ \\
\hline A: Upper middle class (higher managerial, administrative, or professional) & $1(1.3)$ \\
\hline B: Middle class (intermediate managerial, administrative, or professional) & $12(15.6)$ \\
\hline C1: Lower middle class (supervisory or clerical, junior managerial, administrative, or professional) & $31(40.2)$ \\
\hline C2: Skilled working class (skilled manual workers) & $24(31.2)$ \\
\hline D: Working class (semi-skilled and unskilled manual workers) & $5(6.5)$ \\
\hline E: Persons at the lowest level of subsistence, state pensioners or widows (no other wage earner), casual or lowest grade workers & $3(3.9)$ \\
\hline
\end{tabular}


- Moderate Shocks (80, 100, 120);

- Strong Shocks $(140,160,180)$;

- Very Strong Shocks $(200,220,240)$;

- Intense Shocks (260, 280, 300);

- Extremely Intense Shocks $(320,340,360)$;

- Danger: Severe Shocks (380, 400, 420);

- $\operatorname{XXX}(440,460)$.

The music and spotlights were turned on, and the host announced that the game could begin.

According to a predetermined schedule, the contestant responded incorrectly 24 times out of 27 . If the questioner began to hesitate or refused to go on, the host intervened by giving at most five prods to urge the players to continue. The first four prods were worded in a Milgram-like fashion ("Go on with the questions", "Go on, don't let yourself get upset", "The rules say you must go on", "Go on, we are taking all responsibility for this"). Only the fifth prod "You can't make him lose; what does the audience think?" was specific to the television situation; the audience insisted that the game be continued. As in Milgram, starting from when the shock reached 80 volts, the contestant's pre-recorded reactions were heard: grunts at first, then loud cries of pain accompanied by refusal to continue, then screams and pleas to stop the game. After 380 volts, the contestant said he refused to go on. After 420 volts, nothing more could be heard.

The game ended either when the questioner had asked all 27 questions (which involved two shocks of 460 volts) or when, in spite of the host's five prods, the questioner decided to stop. The questioners were informed of the rigging upon leaving the stage. Then, in a calm place, they were debriefed at length.

\subsection{Post-experimental debriefing}

The debriefings were done by a two-person team that was always made up of a psychologist and a specialist in the communication sciences. Five areas were covered:

- demystification, which included the two accomplices (contestant and producer). After the questioners had met the contestant and noticed that he was fine, they were asked to rate their degree of psychological stress as they played the game;

- attributions of responsibility. They rated the extent to which the game producer, the host, the contestant, the audience, and the questioner him/herself were responsible for what happened. The questioner had to divide up 100 points of responsibility among these five persons;

- verbalization of the questioner's feelings, which consisted of letting him/her speak freely without contesting any potential rationalizations;

- statistics-based demonstration that obedience was the most frequent behavior and that the causal weight carried by the situation accounted for this behavior;

- information indicating that the experiment would be incorporated into a TV documentary aimed at opposing certain forms of reality TV. The debriefings lasted between 1 and 2 hours.

\subsection{Measures of obedience}

Like Milgram (1974), we used two obedience measures. One was a binary measure: obedience vs. disobedience. Obedience occurred when the questioner went all the way up to the strongest shock (here, 460 volts); disobedience occurred when the questioner refused to go that high. The second measure was a continuous measure with several degrees of obedience ranging from "absolute refusal" to "absolute obedience". In this case, the criterion was the number of shocks delivered. The theoretical range was 0 to 24 (at most 24 shocks, one per incorrect answer). In our data, the observed values ranged from 5 to 24 .

\section{Results}

\subsection{Results relating to obedience}

First, we compared our results on the binary obedience criterion (Table 4) to Milgram's results in the similar conditions. Our standard condition ( $81 \%$ obedience) did not differ statistically from Milgram's voice-feedback condition $(62.5 \%)\left(\mathrm{Chi}^{2}(1)=3.02, P=.08\right.$; Cramer's $V=0.20)$. Likewise, the host-withdrawal condition (28\% obedience) did not differ from Milgram's condition "experimenter absence" (20.5\%) (Chi ${ }^{2}(1)=0.12, P=.73$; Cramer's V=0.05).

Then we compared our four experimental conditions to each other, again, on the binary obedience criterion. Only the standard condition and the host-withdrawal condition differed significantly (Yates $\mathrm{Chi}^{2}=5.48, P<.02$; Cramer's V=0.45). The standard, socialsupport, and TV-broadcast conditions did not differ, given that the last two conditions did not differ from the host-withdrawal condition (all $\mathrm{Chi}^{2}$ were non-significant). Lastly, the standard, social-support, and TV-broadcast conditions pooled did not differ from the host-withdrawal condition.

On the degree-of-obedience measure (number of shocks delivered), one-way Anova and paired-contrast showed again that only the standard condition differed significantly from the hostwithdrawal condition $(\mathrm{F}(1.72)=5.62, P=.02, d=0.56)$. But this time, the standard, social-support, and TV-broadcast conditions taken together differed $(M=21.2)$ from the host-withdrawal condition $(\mathrm{M}=16.4,[\mathrm{~F}(1.72)=4.75, P=.03, d=0.51])$. Thus, we can oppose the condition that produced the most disobedience (host-withdrawal) to the other three conditions, which mainly produced obedience.

The results indicated that the men and women were equally obedient, which is consistent with many earlier observations (Blass, 1999, 2000) including a recent reproduction of Milgram's experiment (Burger, 2009). There was also no difference between persons from different socio-occupational categories, between the older and younger subjects, or between the avid reality-TV watchers and the others. This absence of differences was found no matter what measure was used: the binary obedience/disobedience criterion or the degree of obedience (number of shocks delivered).

\subsection{Questioners' attributions of responsibility}

At the beginning of the debriefing, the questioner had to divide up 100 points of responsibility among the game producer, the host, him/herself, the audience, and the contestant. As a whole, pairwise comparisons showed that only two pairs did not differ significantly. The first was the questioner $(M=29.17)$ and the producer (who was assigned the greatest amount of responsibility: $M=39.76)$. The second was the audience ( $M=7.487$ ) and the contestant (who was assigned the smallest amount of responsibility: 4.77) (Table 5). All other pairs differenced significantly at $P<.05$ (Table 6 ).

For the partial results concerning the obedient vs. disobedient subjects' attributions of responsibility to the producer vs. the questioner, the means indicated a statistically significant interaction: obedient subjects attributed more responsibility to the producer than to themselves, whereas disobedient subjects did just the opposite (Table 7).

This interaction was significant for the standard, TV-broadcast, and social-support conditions taken together $(F(1.63)=5.08$, $P<.03$ ), three homogeneous conditions in the sense that they were mostly obedience-generating. 
Table 4

Number of obedient questioners and mean number of shocks delivered in the four conditions.

Nombre de questionneurs obéissants et nombre moyen de chocs électriques délivrés dans les quatre conditions.

\begin{tabular}{llll}
\hline Condition & $\begin{array}{l}\text { Standard } \\
(n=32)\end{array}$ & $\begin{array}{l}\text { Social support } \\
(n=19)\end{array}$ & $\begin{array}{l}\text { TV-broadcast } \\
(n=18)\end{array}$ \\
\hline $\begin{array}{l}\text { Number of questioners who went all the way } \\
\text { to the end (obedient) }\end{array}$ & $n=26(81 \%)$ & $n=14(74 \%)$ & $n=13(72 \%)$ \\
$\begin{array}{l}\text { Mean number of shocks delivered (degree of } \\
\text { obedience) }\end{array}$ & $\begin{array}{l}\mathrm{M}=21.91 \\
\mathrm{~s}=4.00\end{array}$ & $\begin{array}{l}\mathrm{M}=20.63 \\
\mathrm{~s}=6.00\end{array}$ & $\begin{array}{l}\mathrm{M}=20.67 \\
\mathrm{~s}=5.97\end{array}$ \\
\hline
\end{tabular}

M: mean; s: standard deviation; (): percentage of obedient subjects in each condition.

Table 5

Attribution of responsibility by obedient and disobedient questioners to the producer, questioner him/herself, host, audience, and contestant.

Attribution de la responsabilité au producteur, questionneur lui/elle-même, animatrice, public et candidat, effectuée par les questionneurs obéissants et désobéissants.

\begin{tabular}{|c|c|c|c|c|c|}
\hline & Producer & Questioner & Host & Audience & Contestant \\
\hline $\begin{array}{l}\text { Obedient subjects } \\
n=51\end{array}$ & $\begin{array}{r}M=43.14 \\
s=34.45\end{array}$ & $\begin{aligned} M & =25.20 \\
S & =29.74\end{aligned}$ & $\begin{aligned} M & =19.20 \\
s & =22.12\end{aligned}$ & $\begin{array}{l}M=7.52 \\
s=15.11\end{array}$ & $\begin{array}{l}M=5.13 \\
s=10.82\end{array}$ \\
\hline $\begin{array}{l}\text { Disobedient subjects } \\
n=20\end{array}$ & $\begin{aligned} M & =30.53 \\
s & =31.31\end{aligned}$ & $\begin{aligned} M & =40.05 \\
s & =34.83\end{aligned}$ & $\begin{array}{r}M=18.26 \\
s=16.38\end{array}$ & $\begin{array}{l}M=7.37 \\
s=13.06\end{array}$ & $\begin{array}{r}M=3.79 \\
s=8.06\end{array}$ \\
\hline $\begin{array}{l}\text { All subjects } \\
n=71\end{array}$ & $\begin{array}{r}M=39.76 \\
S=33.15\end{array}$ & $\begin{aligned} M & =29.17 \\
S & =31.63\end{aligned}$ & $\begin{aligned} M & =18.95 \\
\mathrm{~s} & =20.63\end{aligned}$ & $\begin{array}{l}M=7.48 \\
\mathrm{~s}=14.98\end{array}$ & $\begin{array}{l}M=4.77 \\
s=10.14\end{array}$ \\
\hline
\end{tabular}

M: mean; s: standard deviation. The questioner had to assign responsibility by dividing up 100 points across five targets.

\subsection{Additional results about questioner behavior}

First, to our great surprise, the fifth prod, which was specific to the TV setting (appeal to the audience by the host followed by encouragement to continue from the public), did not have the expected effect. Of the 16 questioners who heard the fifth prod, in the three standard, social-support and TV-broadcast conditions, only one yielded to pressure from the audience. He went all the way up to the highest voltage. The fifth prod turned out to be especially necessary for the disobedient questioners. Most of the obedient ones went to the very end after only two or three prods.

Second, recall that for Milgram, if certain subjects disobey, it is less for moral reasons than to release tension. He noted a number of other tension-reducing phenomena. Even though our experiment was conducted 45 years after Milgram's, and in a very different context, we observed the same phenomena. To begin, the questioners laughed in the moderate-shock range (70\% of questioners laughed openly at 80 volts, when the contestant first makes a complaint). Then at 180 volts, another phenomenon appeared: cheating ( $17 \%$ of the subjects), which consisted of using a tone of voice that made the right answer obvious to the contestant (mode at 220 volts). Lastly, when the contestant screamed at 320 volts (70\% of questioners still in the game), they did what Milgram called "psychological elimination of the contestant" consisting of ignoring the contestant by talking to cover up his screams (mode at 340 volts).

\subsection{Answers to post-experimental questionnaire (5 weeks after the experiment)}

Out of the 76 questionnaires sent out, 64 were returned. The questions fell into four categories: a: reasons for congratulating oneself for having participated; b: reasons for regretting having

Table 6

Comparison of means (F) of questioners' attributions of responsibility (obedient and disobedient subjects pooled, $n=71, \mathrm{df}=70$ ).

Comparaison des moyennes $(F)$ des attributions de responsabilité effectuées par les questionneurs (sujets obéissants et désobéissants regroupés).

\begin{tabular}{llll}
\hline & Producer & Questioner \\
& $\mathrm{M}=39.76$ & $\begin{array}{l}\text { Audience } \\
\mathrm{M}=7.48\end{array}$ & $\mathrm{M}=18.95$ \\
Questioner & $\mathrm{F}=2.34$ & \\
$\mathrm{M}=29.17$ & $(\mathrm{~d}=.37)$ & \\
Host & $\mathrm{F}=15.13^{* * *}$ & $\mathrm{~F}=4.16^{*}$ & $(\mathrm{~d}=.49)$ \\
$\mathrm{M}=18.95$ & $(\mathrm{~d}=.93)$ & $\mathrm{F}=23.43^{* * *}$ & $(\mathrm{~d}=1.16)$ \\
Audience & $\mathrm{F}=48.16^{* * *}$ & $\mathrm{~F}=34.69^{* * *}$ & $(\mathrm{~d}=.91)$ \\
$\mathrm{M}=7.48$ & $(\mathrm{~d}=1.66)$ & $\mathrm{F}=28.52^{* * *}$ \\
Contestant & $\mathrm{F}=64.64^{* * *}$ & $(\mathrm{~d}=1.41)$ & $(\mathrm{d}=1.28)$ \\
$\mathrm{M}=4.77$ & $(\mathrm{~d}=1.92)$ & & $\mathrm{F}=1.82$ \\
\hline
\end{tabular}

M: mean; d: Cohen's d; ${ }^{*} P<.05 ;{ }^{* * *} P<.001$.

Table 7

Attribution of responsibility to the producer and questioner by obedient and disobedient subjects in the standard, TV-broadcast, and social support conditions pooled. Attribution de responsabilité au producteur et au questionneur, effectuée par les sujets obéissants et désobéissants, dans les trois conditions regroupées: standard, passage à la télévision et support social.

\begin{tabular}{llll}
\hline & Producer & Questioner \\
\hline Obedient & $\mathrm{M}=43.67$ & $\mathrm{M}=24.61$ & $\mathrm{~s}=29.91$ \\
& $\mathrm{~s}=33.78$ & $\mathrm{M}=44.07$ \\
Disobedient & $\mathrm{M}=25.33$ & $\mathrm{~s}=35.65$ \\
& $\mathrm{~s}=29.18$ & $\mathrm{~F}(1.63)=4.02(\mathrm{~d}=.65)$ \\
Simple effects (df) & $\mathrm{F}(1.63)=3.61$ & $\mathrm{NS}$ \\
& $P=.06(\mathrm{~d}=.48)$ & $P=04(\mathrm{~d}=.53)$ \\
\hline
\end{tabular}

M: mean; s: standard deviation; $P$ : significance level; d: Cohen's d. 
participated; c: perceptions of the research team; d: attractiveness and utility of new studies. For a, b, and c, the response scale ranged from 0 to 3. For d, the answer choices were "yes" and "no" (Supplementary data):

a) reasons for congratulating oneself for having participated. There were nine questions in this category (e.g. "I learned things about myself", "I learned more about the world of television", "Ilearned things about people", etc.). Only one question obtained a mean below the theoretical mean of 1.5: "It was my chance to be on TV" $(\mathrm{M}=0.84)$. The highest means were found for "It's always interesting to participate in a psychology experiment" $(M=2.42)$ and "We must fight the deleterious effects of reality TV" ( $\mathrm{M}=2.59)$;

b) reasons for regretting having participated. This category included eight questions (e.g. "It was too hard for me", "I would have rather been on a real reality TV show", "People's dark sides should not be revealed like this"). None of the questions reached the theoretical mean of 1.5. The highest mean was observed for the reason "It's too hard for the average person" ( $M=1.2)$. The lowest means were obtained for the questions "I still haven't recovered" ( $M=0.29)$ and "I'm a little afraid of my co-workers' reactions" $(\mathrm{M}=0.47)$;

c) perceptions of the research team (researchers and debriefers). Here, we listed eight traits, with a positive (e.g. warm) or negative (e.g. in a hurry) connotation. The positive traits obtained a mean between 2 and 3 (e.g. competent: $M=2.7$; devoted: $\mathrm{M}=2.5$ ). The negative-trait means were between 0 and 1.5 (e.g. conceited: $=0.42$; nervous: $\mathrm{M}=0.9$ );

d) attractiveness and utility of new studies. This category included six questions, most of which obtained positive responses. For example, $89 \%$ of the questioners answered "yes" to the question "I would participate in a new experiment if the occasion arose"; 94\% answered "yes" to "The producers' project justified our having gone through this".

\section{Discussion}

In the present study, we advance that, in addition to the impact that TV images have on viewers (Bryant and Oliver, 2009; Courbet and Fourquet, 2003; Marchand, 2004), the hold that television has on people is such that, for persons on the stage of a TV game show, it represents an authority strong enough to make them commit clearly immoral or dangerous acts. To demonstrate this, we transposed Milgram's famous experimental obedience paradigm to the context of a TV game show with a live audience and no prizes.

As far as we know, this is the first time Milgram's electric-shock procedure has ever been carefully replicated in a social field where science was not the source of legitimacy for the agent of authority ${ }^{4}$. Here, it was the authority of the television that was at stake. Note that the credibility of the television environment we created was validated by the statistical equivalence of the results obtained in the standard condition (no broadcasting) and the TV-broadcast condition. In this game-show setting, where a host incarnating the televisual authority was present, most people were obedient, i.e., they delivered electric shocks that were as strong and as frequent as the ones used by Milgram, whether they had been told that the show would or would not be broadcasted. This is the first notable result of this research.

\footnotetext{
${ }^{4}$ A few researchers objected that obedience to the authority figure in Milgram's situation was not due solely to his legitimacy. They argued that the authority was also rooted in the attribution of technical skillfulness for operating the device (Blass and Schmitt, 2001; Morelli, 1983). Here, one cannot ascribe any observed obedience to some assumed skillfulness the host might have had for operating the electricshock device, since she was known as a TV weather forecaster.
}

It seems, then, that even in highly different contexts, the determining factor is the physical proximity of a person invested with the right to give orders (even if only temporarily). The second notable result of this research arises from the fact that the only experimental condition that triggered significantly more disobedience (to extents like those found by Milgram) was the condition where the agent of authority went off stage. Despite the small sample size for this experimental condition, its confirmation of one of Milgram's results adds to its merit.

We thus attributed obedience behaviors to the prescriptive power delegated to the host position. However, two alternative interpretations must be considered. The first alternative interpretation involves the influence of the televisual environment: the cameras, music, projectors, monitors, audience, technicians running back and forth, cameramen filming, etc. These factors all contributed to the authenticity of the televisual environment, impressed subjects and contributed to their implication in the show's concept and its success. It is therefore legitimate to wonder if the obedience was a product of this influence. Two arguments allow us to answer in the negative. First, though audience intervention is a strong element in the televisual environment, we found that audience intervention (fifth prod) encouraging the questioner to continue did not have the anticipated effect. The second argument stems from the condition where disobedience is observed: when the host leaves the set. Though the host is absent, the televisual environment remains unchanged (lights, projectors, cameras, audience, etc.).

The second alterative interpretation involves the subjects' commitment to the situation. Subjects went through various phases beginning with their arrival in the studio. They met the producer who, after giving them information about the game and about their role, asked them to decide whether or not they would like to proceed. They then spend some time with the make-up artist who prepared them for the show. At this point, subjects can still leave. They then had a first meeting with the host and the contestant. The hosts asked them if everything was OK. The subjects answered yes. Subjects are thus in a situation which is particularly binding, a situation which, up to this point, is governed by what is defined, operationally, as free choice. In theory, this combination primes them for other freely chosen behaviors that follow the course of action (Joule and Beauvois, 1998). We must nevertheless eliminate this second interpretation of obedience. When the subjects arrive on the set, the situation changes, effectively marking the end of the free-choice ${ }^{5}$. They are now in front of a host who gives them instructions, "Continue. Do not let yourself be influenced..." These instructions are typical of power situations where the host has received a delegation. It is no longer a matter of choosing or deciding, but rather of obeying or disobeying the host. Even if subjects are committed, when the host leaves, subjects may disobey, and this is in fact what they do most of the time. We are led to conclude that our results are due to the host's position as a power agent, comparable to Milgram's researcher.

If the behavioral data obtained in this study was very similar to Milgram's, so was the attribution data collected during the debriefing. Our questioners attributed a large part of the responsibility to themselves. Like Milgram, we can suggest that these attributions were rooted in a retrospective interpretation of what happened. When answering the responsibility question, the questioners were no longer in the experimental situation, so they could rationalize their behavior. To do so, they may have looked for explanations in the Zeitgeist and in today's prevailing norms,

\footnotetext{
${ }^{5}$ We are not suggesting that the subjects are being deprived of basic freedom but the fact that they are no longer invited to decide operationally characterizes commitment situations (Beauvois, 2005, 2011).
} 
which prompt us to be held accountable for our acts (Beauvois and Dubois, 1988; Dubois, 2009; Dubois and Beauvois, 2008). Note, however, that unlike the disobedient subjects, the obedient ones attributed less responsibility to themselves - in line with the pattern of the agent state - than to the producer. This is consistent with Milgram's (1974) idea that the very fact of being an agent means accepting oneself as an executing agent for some other agent of power, the latter of whom is the one held responsible for what happens.

A striking thing here is that the condition where social support for disobedience was provided by an assistant who arrived on stage and requested that the game be stopped because it was becoming dangerous did not produce disobedience. This troubling finding has been observed recently by other researchers: conditions designed to produce disobedience, and which produced disobedience under Milgram's experimental conditions, have ended up producing mostly obedience. Burger (2009), for example, found that the intervention of an accomplice who refused to continue did not generate the expected disobedience. Could it be that the period we are living in predisposes people to greater obedience ${ }^{6}$ ? What we found here in the television studio is that obedience continues to be a reality, at a time when many authors believe that our societies are evolving instead toward greater permissiveness, toward more "negotiated" powers and even toward the end of authority altogether (Friedberg, 1997; Lemel and Galland, 1988). While this is not sufficient to make the argument that current times encourage greater obedience than was the case in the 1960s, our observations, like those of Burger, warrant at least some skepticism about theses like that of the end of authority. They also help us understand why, in today's liberal society, "moral rebels" may be stigmatized (Monin et al., 2008).

It has long been known that television, and so television hosts, had influence on viewers. We suspected they could also have prescriptive power for ordering people's behavior on a television stage, including contrattitudinal, cruel and immoral behaviors. But it had never been shown. The present research demonstrates this aspect. This sheer fact should put TV show producers and channels face to face with their potential responsibility for possible deleterious effects of reality TV games and shows.

\section{Disclosure of interest}

The authors declare that they have no conflicts of interest concerning this article.

\section{Appendix A. Supplementary data}

Supplementary data associated with this article can be found, in the online version, at http://www.sciencedirect.com and doi:10.1016/j.erap.2012.02.001.

\section{References}

Beauvois, J.-L, 2005. Les Illusions libérales. Petit traité des grandes illusions [The liberal illusions. Little treatise of the great illusions]. Presses Universitaires de Grenoble, Grenoble.

Beauvois, J.-L., 2011. Les influences sournoises [The insidious influences]. FrançoisBourin, Paris.

Beauvois, J.-L., Dubois, N., 1988. The norm of internality in the explanation of psychological events. European Journal of Social Psychology 18 , 299-316.
Berkowitz, L., 1986. Situational influences on reactions to observed violence. Journal of Social Issues 42 (3), 93-106.

Blass, T., Schmitt, C., 2001. The nature of perceived authority in the Milgram paradigm: two replications. Current Psychology 20,115-121.

Blass, T. (Ed.), 2000. Obedience to authority: current perspectives on the Milgram paradigm. Lawrence Erlbaum Associates, Mahwah, NJ.

Blass, T., 1999. The Milgram paradigm after 35 years: Some things we now know about obedience to authority. Journal of Applied Social Psychology 29, 955-978.

Blass, T., 2009. From New Haven to Santa Clara: a historical perspective on the Milgram obedience experiments. American Psychologist 64, 37-45.

Bryant, J., Oliver, M.B. (Eds.), 2009. Media effects: advances in theory and research. Routledge, New York.

Burger, J.M., 2009. Replicating Milgram: would people still obey today? American Psychologist 64, 1-11.

Coenen-Huther, J., 2005. Pouvoir, autorité, légitimité. En marge d'un livre récent d'Alain Renaut [Power, authority, legitimacy. On the sidelines of a recent book by Alain Renaut]. Revue Européenne de Sciences Sociales 43, 135-145.

Courbet, D., Fourquet, M.-P. (Eds.), 2003. La télévision et ses influences [The television and its influences]. De Boeck, Bruxelles.

De Vos, J., 2010. From Milgram to Zimbardo: the double birth of postwar psychology/ psychologization [The norm of internality and the liberalism]. History of the Human Sciences 23 (5), 156-175.

Dubois, N., 2009. La norme d'internalité et le libéralisme. Presses Universitaires de Grenoble, Grenoble.

Dubois, N., Beauvois, J.-L., 2008. The social value of internal explanations and the norm of internality theory. Personality and Social Psychology Compass 2, 1737-1752.

Friedberg, E., 1997. Le pouvoir et la règle [The power and the rule]. Le Seuil, Paris.

Haslam, S.A., Reicher, S., 2006. Stressing the group: social identity and the unfolding dynamics of responses to stress. Journal of Applied Psychology 91 (5), 1037-1052.

Joule, R.-V., Beauvois, J.-L., 1998. La soumission librement consentie (The free accepted compliance). Presses Universitaires de France, Paris.

Lemel, Y., Galland, O., 1988. La nouvelle société française. Trente ans de mutation [The new French society. Thirty years of change]. Armand Colin, Paris.

Marchand, P. (Ed.), 2004. Psychologie sociale des médias [Social psychology of media]. Presses Universitaires de Rennes, Rennes.

McGuire, W.J., 1986. The myth of massive media impact. In: Comstock, C.(Ed.), Public communication and behavior. Academic Press, Orlando.

Meeus, W., Raaijmakers, Q., 1986. Administrative obedience: carrying out orders to use psychological-administrative violence. European Journal of Social Psychology $16,311-324$

Meeus, W., Raaijmakers, Q., 1987. Administrative obedience as a social phenomenon. In: Doise, W., Moscovici, S. (Eds.), Current issues in European social psychology. Cambridge University Press, Cambridge, pp. 183-230.

Milgram, S., 1963. Behavioural study of obedience. Journal of Abnormal and Social Psychology 67, 371-378.

Milgram, S., 1974. Obedience to authority. An experimental view. Harper, Row, New York.

Miller, A.B., 1986. The obedience experiments: a case study of controversy in social science. Praeger, New York.

Monin, B., Sawyer, P.J. Marquez, M.J., 2008. The rejection of moral rebels: resenting those who do the right thing. Journal of Personality and Social Psychology 95 (1), 76-93.

Morelli, M., 1983. Milgram's dilemma of obedience. Metaphilosophy 14, 183-189.

Nabi, R.L., Hendriks, A., 2003. The persuasive effect of host and audience reaction shots in television talk shows. Journal of Communication 53 (3), 527-543.

Oberlé, D., Beauvois, J., Courbet, D., 2011. Une transposition du paradigme d'obéissance de Milgram à la télévision: enjeux, résultats et perspectives [Applying Milgram's obedience paradigm to television: issues, results and prospects]. Connexions 95 (1), 71.

Packer, D.J., 2008. Identifying systematic disobedience in Milgram's obedience experiments: a meta-analytic review. Perspectives on Psychological Science 3 (4), 301-304.

Reicher, S., Haslam, S.A., 2011. After shock? Towards a social identity explanation of the Milgram "obedience" studies. British Journal of Social Psychology 50 (1), $163-169$.

Russell, N.J.C., 2011. Milgram's obedience to authority experiments: origins and early evolution. British Journal of Social Psychology 50 (1), 140-162. 